\title{
Where's the Justice? Affirmative Action's Severed Civil Rights Roots in the Age of Diversity
}

\author{
Daniel N. Lipson
}

\begin{abstract}
The institutionalization of race-conscious inclusion policies in employment, education, and contracting has largely endured in post-civil rights America despite predictions of their demise. However, scholarship has continued to mislabel many of the specific policies in these organizations and governments as "affirmative action" policies, even though many such policies lack the civil rights roots necessary to warrant this label. In this article, I explain how many organizations have recast, supplemented, or replaced their rights-based affirmative action policies with utilitarian diversity policies. While the conventional, civil rights framework for analyzing affirmative action obscures the rise of such organizational diversity policies, an alternative body of scholarship that employs a diversity framework has shed light on the causes, content, and consequences of this policy and political realignment. The Supreme Court's 2003 Grutter v. Bollinger decision and the political activism surrounding Michigan's Proposal 2 in 2006 both exemplify the trademark signs of this shift from rights-based affirmative action to organizational diversity policies. The article concludes by assessing the promise and dangers of this trend of rooting racial inclusion policies in a utilitarian diversity logic rather than a civil rights logic.
\end{abstract}

$\mathrm{n}$ the past three decades, courts have chipped away at the use of the corrective justice basis for voluntary, racebased inclusion policies. Organizations practicing such policies have shifted to utilitarian rationales that emphasize the value of diversity. As this diversity framework has become institutionalized, new coalitions of powerful prodiversity interests have sidelined traditional civil rights organizations from the public spotlight in their mobilization efforts to fend off "colorblind" litigation and ballot measures. As can be seen in both the 2003 Grutter v. Bollinger lawsuit over admissions policies at the University of Michigan Law School and also in the battle over Michigan's Proposal 2 on the November 2006 ballot, the coordinated legal and political defense of affirmative action has deemphasized rights-based logic, instead privileging instrumental arguments rooted in the benefits accruing to organizations as a result of diversity. ${ }^{1}$

\footnotetext{
Daniel N. Lipson is Assistant Professor of Political Science at the State University of New York at New Paltz (lipsond@newpaltz.edu). The author thanks Amy Elman, Stephen Wasby, John Skrentny, Jennifer Hochschild, Thomas Keck, Donald Downs, Howard Erlanger, Susan Hoffmann, Anna Kirkland, and the anonymous reviewers for their valuable comments. An earlier version of this paper was presented at the 2004 Canadian Political Science Association Annual Conference.
}

According to the conventional, civil rights framework for analyzing affirmative action policy and politics, the debate over this controversial issue is fundamentally a partisan and ideological struggle over the principle of equality. ${ }^{2}$ According to this framework, liberal and Democratic voters, interest groups, and lawmakers embrace the antisubordination principle - which Siegel defines as "the conviction that it is wrong for the state to engage in practices that enforce the inferior social status of historically oppressed groups" ${ }^{3}$ - and view affirmative action as central to the civil rights agenda. In contrast, opposition to affirmative action according to the civil rights framework is primarily rooted in adherence to the anti-classification principle-which Siegel defines as "the constitutional principle that government may not classify on the basis of race" ${ }^{4}$ - and comes largely from conservatives and Republicans, who view the granting of "special rights" to women and racial minorities as "reverse discrimination" against whites and males." 5

Of course, each side of the conflict claims to take the high road of adherence to principles while accusing the other side of pursuing self-interest or even bigotry. Many affirmative action proponents attribute opposition to self-interest and backlash rooted in racial resentment. ${ }^{6}$ Conversely, many affirmative action opponents accuse government and organizations of caving in to "special interest" pressure by liberal civil rights groups and "civil rights professionals,"7 who create a "racial spoils system" out of self-interest. ${ }^{8}$ According to the civil rights 
framework, each side views its own agenda as promoting civil rights, even if each side may view the opposing side as pursuing a self-interested agenda.

The civil rights framework remains the prevailing framework employed by scholars, journalists, lawmakers, and ordinary citizens to understand affirmative action. In contrast, a number of scholars have applied a utilitarian, diversity framework to analyze the emergence of a variety of affirmative action that has been severed from its civil rights roots. Such authors emphasize that, since the early 1980s, affirmative action has garnered substantial support especially from high-profile leaders of corporations, the Republican Party, and executive agencies (including most notably the Department of Defense). ${ }^{9}$ Some of these scholars argue that distinct varieties of affirmative action have emerged that are separate from the original, rights-based affirmative action. For example, Frymer and Skrentny distinguish instrumental affirmative action from rights-based affirmative action in the following way: "[Instrumental affirmative action is] more likely to emphasize economics, community and social stability. .. And unlike traditional affirmative action law, its logic is based on considerations of the present or future, ignoring historical discrimination and in turn, ignoring structural power differences." ${ }^{10}$ Other scholars claim that the core affirmative action policy remains intact and largely unchanged but identify differing rationales employed to justify the same policy. ${ }^{11}$

I first make the case for a revised terminology to more precisely categorize and analyze the population of racial inclusion policies. In this section, I situate both racebased affirmative action and related race-based diversity policies within an overarching set of racial inclusion policies. The second section traces the civil rights roots of early race-based affirmative action policies. I then examine the gradual rise of organizational diversity policies as supplementing or displacing rights-based affirmative action policies. Next, I argue that the Supreme Court case (Grutter v. Bollinger) in 2003 concerning race-conscious admissions at the University of Michigan along with the 2006 ballot measure (Proposal 2) banning affirmative action in Michigan serve as evidence of the realignments from rightsbased affirmative action practices to instrumental-based diversity practices. This section also incorporates the 2007 Supreme Court ruling in Parents Involved in Community Schools v. Seattle School District No. $1^{12}$ to support my argument that recasting rights-based affirmative action into organizational diversity policies has contributed to protecting the habitat of such race-conscious diversity policies. In this new form, race-conscious inclusion policies have become more institutionalized - and much less endangered - than many experts have thus far predicted. The conclusion speculates on the future lifespan and development of these race-conscious diversity measures that are commonly, but problematically, still called "affirmative action” policies. Finally, I analyze numerous scholars' calls for the renewal of rights-based affirmative action alongside organizational diversity policies.

\section{A Revised Typology for Categorizing Racial Inclusion Policies}

This section sets out to situate rights-based affirmative action and instrumental based-diversity policies within a more precise typology of the larger set of racial inclusion policies. "Affirmative action" continues to be commonly used as a catch-all label for all race-conscious policies that seek racial diversity. In contrast, a smaller number of scholars have argued that affirmative action has been partially or entirely replaced by "diversity management" or related diversity policies. ${ }^{13}$ Still other scholars have found that a substantial percentage of organizations and government agencies continue to enact the same policy with no or few substantive changes by merely replacing civil rights rationales with diversity rationales to bolster the legal defense of affirmative action policies or renaming their affirmative action policies as diversity or diversity management policies. ${ }^{14}$

The initial meaning of affirmative action when the concept and policy originated in the 1960s is much more akin to what today is called equal opportunity or aggressive enforcement of non-discrimination. ${ }^{15}$ The aggressive, "hard" policy that has become central to the contemporary definition of affirmative action existed alongside "soft" affirmative action since the inception of affirmative action. Organizations employ soft affirmative action when they make active efforts to include individuals from historically excluded racial groups by increasing the pool of applicants at early stages so that hard affirmative action at later stages becomes less necessary. Today, the usage of the phrase affirmative action generally corresponds to hard affirmative action; that is, the concept of affirmative action is used to refer to special consideration (whether goals and timetables, preferences, or-in certain rare cases - quotas) being granted to members of previously excluded racial groups. ${ }^{16}$ In the early years of affirmative action, one type of hard affirmative action practice in the employment sector involved courts requiring employers to award seniority to African American employees based on when they should have been promoted upon findings of actual discrimination. In higher education today, the awarding of preferences in the admission process to applicants from underrepresented racial groups is one common form of hard affirmative action.

Whereas many critics frame affirmative action as preferences for preferences' sake, this is not in line with the original intent or core meaning of affirmative action. Policies preferring racial minorities should be referred to as affirmative action policies only if they are rooted in a civil rights justification. Two policies may be functionally equivalent, but one may be designed with the rights-based goal 
of corrective justice and another may be explicitly designed as an instrumental policy to achieve diversity in order to improve national security or corporate sales. Both are racial diversity policies. But only the former, according to commonly accepted definitions, is an affirmative action policy.

While this distinction may seem merely semantic, it is in most cases not in practice. When leaders of institutions rely on race-conscious diversity policies in order to improve their performance, they feel no sense of obligation to provide special consideration either to socio-economically disadvantaged minorities or to members of historically subordinated minority groups. As I explain below, "affirmative action" policies in education, employment, and contracting have increasingly benefited privileged immigrants of color at the expense of African Americans, American Indians, and Hispanics. In addition, Kelly and Dobbins raise additional economic concerns about recasting affirmative action as diversity policy: "But precisely because it is founded on cost-benefit analysis rather than on legal compliance, perhaps diversity management will come under the ax of corporate budget-cutters when America faces its next recession." 17

The term affirmative action has been-and continues to be-misused so pervasively and flagrantly that established scholars have joined pundits in mislabeling preferences for legacies and other privileged whites or males as "affirmative action for whites" or "affirmative action for legacies." For example, Massey refers to affirmative action for minorities, for athletes, and for legacies as "America's Three Affirmative Action Programs," 18 and Katznelson refers to the era of New Deal-era social welfare policies that privileged whites and largely excluded blacks as the era "when affirmative action was white." 19 Proponents of affirmative action commonly argue that President George W. Bush is hypocritical for opposing race-based affirmative action because he himself was an affirmative action legacy recipient at Yale University. ${ }^{20}$ But these are abuses of language, given that the concept "affirmative action" by virtually all accepted definitions refers to a policy that provides special consideration to women or racial minority applicants in an effort to further equality by including members of groups that have historically been subordinated. Preferences for whites, males, legacies, and athletes fail to contain the civil rights component of equality concerns needed to be considered affirmative action policies; neither has suffered from a history of subordination.

I designate the term "racial inclusion policies" for the broad set of policies that seek the outcome of racial diversity by striving to include members of historically marginalized racial groups. Figure 1 provides a typology of racial inclusion policies in a two-by-two grid, where the rows distinguish between policies rooted in civil rights rationales versus organizational diversity rationales and the columns distinguish between measures that use race-conscious means versus race-neutral means to achieve racial diversity.
Figure 1

A typology of racial inclusion policies

\begin{tabular}{|c|c|c|}
\hline Civil rights & $\begin{array}{l}\text { Race-conscious } \\
\text { measures } \\
\text { Affirmative action }\end{array}$ & $\begin{array}{l}\text { Race-neutral } \\
\text { measures } \\
\text { Equal opportunity }\end{array}$ \\
\hline policies & policies & $\begin{array}{l}\text { policies } \\
\text { p }\end{array}$ \\
\hline $\begin{array}{l}\text { Diversity } \\
\text { policies }\end{array}$ & Diversity policies & Adversity policies \\
\hline
\end{tabular}

This terminology is more precise than the commonly used labels because it distinguishes racial inclusion policies according to their core components: who is targeted (beneficiaries), how the policy operates (methods), and why the policy exists (rationale). Instead of on the one hand heeding calls to eliminate the phrase affirmative action from the lexicon or on the other hand overusing it to describe policies counter to its core meaning, the typology I propose relies on precise and relatively concise language to more effectively and accurately categorize and analyze policies designed to achieve racial inclusion and diversity.

\section{The Civil Rights Roots of Affirmative Action}

While a small number of scholars have traced the genesis of race-based affirmative action to War Department policies and Public Works Administration (PWA) policies in the $1930 \mathrm{~s},{ }^{21}$ such governmental actions have more commonly been considered precursors to affirmative action. The emergence of affirmative action in the U.S. dates back to Presidents Kennedy (via Executive Order 10925), Johnson (via Executive Order 11246), and Nixon (via the Department of Labor's institution of the Revised Philadelphia Plan). ${ }^{22}$ In its inception, proponents supported a policy that was rooted in a group-based vision of equality. ${ }^{23}$

Non-discrimination policies were seen by early affirmative action supporters as necessary but not sufficient to achieve this goal. Early on, President Lyndon Johnson articulated this case for group-based equality in his remarkable Howard University commencement speech, arguing that it would be highly problematic to "take a man who for years has been hobbled by chains, liberate him, bring him to the starting line of a race, saying, 'you are free to compete with all the others,' and still justly believe you have been completely fair." ${ }^{24}$ Supreme Court Justice Harry Blackmun lent his voice to this group-based argument when he wrote in his Regents of the University of California v. Bakke dissenting opinion that "in order to get beyond racism, we must first take account of race. There is no other way." ${ }^{25}$ In contrast, "colorblind" advocates call for a competing vision of equality that relies on equal opportunity at 
the individual level. ${ }^{26}$ In accordance with this view, to quote Justice Harlan, "Our Constitution is colorblind, and neither knows nor tolerates classes among citizens." 27 Colorblind supporters argue that racial preferences constitute reverse discrimination ${ }^{28}$ and, to quote John F. Kennedy, that "race has no place in American life or law." 29 Current Supreme Court Justices Scalia and Thomas have continued to adhere to this conception of colorblindness.

While even early affirmative action policies targeted other racial minorities in addition to African Americans, ${ }^{30}$ the debate primarily centered on whether and how to give special consideration for African Americans. ${ }^{31}$ The early and enduring extension of race-based affirmative action to Hispanics, Native Americans, Aleuts, Asian Americans, and other racial and ethnic minorities in employment, ${ }^{32}$ contracting, ${ }^{33}$ and university admissions ${ }^{34}$ occurred with little deliberation or guidance. The inclusion of these other groups comprising Americass "official minorities" 35 has provided further grounds for criticizing affirmative action, for opponents argue that the policy has become a patronage system ${ }^{36}$ awarding benefits to people of color without rooting the race-targeting in coherent, consistent civil rights justifications. Instead, in the eyes of critics, race-based affirmative action has become a policy that punishes whites (and Asians) for their honesty in self-identifying as white and rewarding African American, Hispanic, and American Indian applicants merely for checking these arbitrary "little boxes" on application forms. ${ }^{37}$

Publicly-stated civil rights rationales might serve as a cover for instrumental motives. Karabel's research about the development of admissions policies at Harvard, Yale, and Princeton found that "fear of social disintegration" during the urban racial unrest of the late 1960s-rather than civil rights commitments-motivated the creation of vigorous race-based affirmative action policies at these "Big Three" Ivy League universities. Karabel's research uncovered that "the dominant theme in the texts of the period was neither diversity nor compensation for past injustices, but rather the need for 'Negro leadership'" to steer black urban communities past the perceived crisis of urban racial unrest. ${ }^{38}$ This crisis management explanation for the genesis of affirmative action in higher education is consistent with a body of scholarship tracing the role of crisis management in the emergence of affirmative action in both employment ${ }^{39}$ and contracting. ${ }^{40}$

Regardless of the strategic political motives behind the origins of affirmative action, the definitional distinction still holds that racial inclusion policies are not affirmative action policies unless they are implicitly or explicitly rooted in a civil rights rationale of seeking to achieve equality by actively including members of historically excluded racial groups. The next section analyzes the gradual expansion of organizational diversity policies, which in some cases replaced and in other cases supplemented rights-based affirmative action policies.

\section{The Institutionalization of Racial Diversity Policies}

Scholars of affirmative action understandably greet attempts to make sweeping generalizations about the transformation of affirmative action and related racial diversity policies with great suspicion, for the development of particular policies varies tremendously. After all, the historical context of affirmative action differs greatly across the sectors of education, employment, and contracting. As difficult and problematic as it may be to generalize about the development of affirmative action and racial diversity policies, certain trends have nonetheless extended across all three sectors. The most profound development has been that diversity policies in many realms have supplemented or replaced race-based affirmative action policies. As Frymer and Skrentny argue, "Affirmative action in the United States has been cut loose from its moorings in the nation's tragic history of racial oppression and the law that developed to remedy that oppression. Increasingly, it is rooted in strategies to maximize the performance of institutions." 41

In all three sectors, race-based affirmative action emerged in part as a crisis management response at a time of race rioting in America's cities and of racial protests consuming many college campuses. ${ }^{42}$ These instrumental arguments receded in government agencies, universities, and corporations, but they returned in the 1980s as a reaction both to the anti-affirmative action legal environment and to the accompanying rise of "diversity management." ${ }^{43}$ The discourse of diversity as a rationale for affirmative action originated in higher education, as is clear in Justice Powell's Bakke opinion. In the employment sector, the "Workforce 2000" report by the Department of Labor under President Reagan was influential in calling attention to the importance of reaching out to racial minorities who were absent from large sectors of the workforce. ${ }^{44}$

The rise of diversity management as both supplement and alternative to affirmative action has been a profound development in the workforce. The concept of diversity management was first coined by R. Roosevelt Thomas, ${ }^{45}$ who has devised a model for businesses to capitalize on the strengths associated with racial and other forms of diversity in all segments of business operations. According to Kelly and Dobbin, diversity management in practice relied primarily on the following strategies that had been repackaged from previously existing equal employment opportunity (EEO) and affirmative action (AA) programs: "announcing the organization's commitment to nondiscrimination, training managers and holding them accountable, providing career development advice, encouraging mentors and network contacts, and identifying career paths." 46

Thomas has in places conceptualized diversity management as a race-neutral managerial policy that replaces affirmative action by "embracing diversity" without racial targeting and a reframing of affirmative action from a civil 
rights framework to an instrumental diversity framework. ${ }^{47}$ In his seminal 1990 article, Thomas predicted that "sooner or later, affirmative action will die a natural death." ${ }^{48}$ On the other hand, this diversity management model, notes Kellough, "looked very much like traditional affirmative action" in many respects. ${ }^{49}$ More recently, as Kellough argues, "beleaguered supporters of traditional equal employment opportunity and affirmative action. . . [have taken] refuge in the diversity management paradigm ... as the decade of the 1990s advanced." 50

Scholars of organizations have traced this rise of diversity management to a variety of interconnected factors: conservative judicial decisions that were highly restrictive of affirmative action created the incentive to institute diversity management, the professional socialization of equal employment opportunity and other diversity professionals fostered organizational support for diversity management, and legal ambiguity concerning the terms of compliance provided diversity professionals with the ample discretion needed to rework their policies. ${ }^{51}$ In the context of adverse Supreme Court decisions and Democratic President Bill Clinton's lukewarm defense of affirmative action, affirmative action appeared to many experts to be endangered by the early 1990 s. $^{52}$ Diversity specialists found in diversity management rhetoric a promising way to repackage equal employment opportunity and affirmative action programs. ${ }^{53}$ The shift from affirmative action to diversity management programs was in part "old wine in new wineskins," $"$ but it also was a wise legal strategy in that "these specialists were able to prevent, or at least forestall, the deinstitutionalization of their programs and departments." 55

Affirmative action in contracting was also marked by the shift from civil rights roots to diversity roots, especially in the 1980s and 1990s. As Anderson explains, affirmative action policy emerged in the contracting sector in the form of set-asides as a response to urban rioting in the mid- to late-1960s. As early as 1973, the Small Business Administration program defined disadvantaged people to include not only people of African descent but also those of Hispanic, Native American, and Asian descent. In many agencies, "disadvantaged" companies received financial bonuses or else winning bids if their bid was within 10 percent of the non-minority competitor companies' bids. ${ }^{56}$ Anderson pointed out the taken-for-granted nature of this early expansion of affirmative action policies to the full cast of what Skrentny dubs "official minorities"; ${ }^{57}$ bureaucrats received little political guidance and expanded the beneficiaries without any clearly formulated rationale. ${ }^{58}$

In education, employment, and contracting, immigrants make up a significant proportion of beneficiaries. For example, a recent study by Massey has found that selective colleges and universities are sustaining or bolstering their black student enrollments by increasing admissions of upper-middle class, recent black immigrants from
Africa, the West Indies, and Latin America at the expense of disadvantaged black Americans who suffer from the legacies of slavery and Jim Crow segregation. ${ }^{59}$ The original intent of the university and contracting programs was to help African Americans of modest means. In contracting, too, many immigrants benefiting from affirmative action were and still are professionals (e.g., engineering, computer programmers, professors, etc.) rather than lowsocioeconomic status African American beneficiaries. ${ }^{60}$

The embrace of diversity in higher education emerged early on, as Karabel and Douglass have both documented in their research on elite private and public universities, respectively. ${ }^{61}$ Early policies in the late 1960 s were rooted in civil rights rationales alongside diversity and opportunity rationales. Justice Powell's Bakke opinion closed the door on remedying "societal discrimination" as a rationale for race-conscious admissions, but he provided what amounted to an advisory opinion with his praise of the race-conscious individual assessment policy employed by Harvard University that was justified in terms of the educational value of diversity. Except for specific universitiespredominantly in the South-under consent decrees or court-mandated desegregation orders, situations in which quotas still are legal, selective universities largely abandoned civil rights rationales for their race-conscious admissions policies and instead prominently featured preferences rooted in the diversity rationale. ${ }^{62}$

Scholars have found strong and longstanding commitments to promoting racial diversity among admissions professionals, faculty involved with admissions, and other top administrators at both selective undergraduate institutions and at professional schools. ${ }^{63}$ When race-conscious admissions policies were banned by federal courts and ballot measures in several states beginning in the 1990s, university officials quickly instituted innovative raceneutral diversity policies, some of them cast in terms of overcoming students' disadvantage, in an effort to rapidly restore the racial diversity levels. ${ }^{64}$ Such reforms have included individual assessment policies rather than formula-based admissions. ${ }^{65}$ In addition, selective universities in Texas, California, and Florida seek to restore racial diversity levels by capitalizing on highly segregated school districts through "percentage plans," which guarantee admission to students with the top grade point averages in their state high schools; such guarantees lead to admitting large numbers of African American and Hispanic students in states with large numbers of predominantly black and Hispanic high schools.

As public university leaders in California, Texas, Washington, and Florida were experimenting with creative "adversity policies," university leaders in the rest of the country were bolstering their case for race-conscious admissions and rallying to the defense of the University of Michigan as its two court cases traversed their long and arduous path to the Supreme Court. The next section will analyze 
the instrumental nature of this support for race-conscious diversity policies, examining the 2006 Michigan Proposal 2 in addition to the Grutter v. Bollinger decision as further signs of the shift from rights-based affirmative action to organizational diversity policies.

\section{Affirmative Action as a Debate between Conservative Supporters and Opponents}

According to the civil rights framework, liberal civil rights organizations would line up to defend affirmative action as an essential policy to remedy discrimination and to ensure that African Americans be included in elite institutions from which they were historically excluded. One might expect that the Republican Party and its allied interests would take a firm stance against race-based affirmative action. And one might expect the debate over the fate of race-based affirmative action to hinge on principled debates over conceptions of equality. The strand of affirmative action scholarship that is rooted in the civil rights framework has portrayed the debate as generally falling along these partisan and ideological cleavages. ${ }^{66}$ Much about the civil rights framework is correct, and thus the numerous scholars who portray the affirmative action debate in this way are able to make persuasive arguments about the conservative mobilization against race-based affirmative action.

However, to view the affirmative action controversy largely through the conventional, civil rights framework is to miss out on a transformation that has been underway over the past generation. On June 23, 2003, the United States Supreme Court handed down the landmark Grutter $v$. Bollinger decision. In a sharply divided 5-4 decision, Justice O'Connor's majority opinion held that diversity is a "compelling governmental interest" for race-conscious university admissions policies and that the University of Michigan Law School's particular policy constituted a "narrowly tailored means" of achieving this compelling governmental interest. Grutter $v$. Bollinger, and its companion, Gratz v. Bollinger, ${ }^{67}$ reveal three major changes. First, as I have argued earlier, the racial diversity politics and policies have to a significant degree displaced rights-based affirmative action politics and policies. Second, the case for "affirmative action" in conflicts over litigation and ballot measures has increasingly privileged conservative arguments about business management and military cohesion while de-centering principled liberal arguments about social justice. In this sense, the debate over affirmative action-especially in litigation and ballot measures - has increasingly featured the rift among conservatives. This conservative debate has partially displaced the classic cleavage between liberals and conservatives. Rights-based colorblind conservatives increasingly view their cause as the David that is going up against the pro-affirmative action Goliaths (especially the military and Fortune 500 companies). Third, Republican Party leaders remain hesitant to actively oppose affirmative action, in large part for electoral reasons. I have already examined the first claim above. The following sections will elaborate on the second and third claims.

On the one hand, the shift from affirmative action to diversity policies has nudged racial policy and politics in a conservative direction ${ }^{68}$ as attention focuses on how racial diversity helps large organizations to further their own interests rather than on how affirmative action can promote social justice for its recipients. On the other hand, these institutions' embrace of race-conscious diversity policies has transformed the institutions-and American law-in a liberal direction. These large organizations at least symbolically embrace tolerance and diversity, which are key components of the contemporary liberal paradigm of racial inclusion. And these organizations-by actively defending race-conscious diversity policies-have played an important role in stalling the conservative colorblind attack. ${ }^{69}$ Thus, diversity professionals have transformed their organizations in a liberal direction, but in doing so they have also contributed to transforming affirmative action policy in a conservative, utilitarian direction.

In the Grutter decision, Justice O'Connor relied heavily on the amicus briefs filed by the military brass and Fortune 500 companies, which played a prominent role in the oral arguments for the cases in spring 2003. Note how O'Connor relies on both sets of briefs in her Grutter majority opinion:

These benefits are not theoretical but real, as major American
businesses have made clear that the skills needed in today's increas-
ingly global marketplace can only be developed through expo-
sure to widely diverse people, cultures, ideas, and viewpoints.
Brief for $3 \mathrm{M}$ et al. as Amici Curiae 5; Brief for General Motors
Corp. as Amicus Curiae 3-4. What is more, high-ranking retired
officers and civilian leaders of the U.S. military assert that, '[b]ased
on [their] decades of experience,' a 'highly qualified, racially
diverse officer corps. . . is essential to the military's ability to
fulfill its principle [sic] mission to provide national security. Brief
for Julius W. Becton, Jr. et al. as Amici Curiae 27.'70

O'Connor's notable focus on these briefs illuminated this transformation in affirmative action politics that has been underway for a generation.

Many scholars were surprised by these briefs in favor of the University of Michigan affirmative action policies. ${ }^{71}$ Indeed, on one level, there are good reasons to be surprised. After all, the military and corporations are viewed as conservative both in their missions and workforces. Both have traditionally been associated as core constituencies for a Republican Party that has, for much of the latter half of the twentieth century, engaged in a southern strategy of "playing the race card" in order to lure white moderates from the Democratic Party. ${ }^{72}$ Given the perception that proponents of affirmative action are disproportionately 
liberal, females, and people of color, it is surprising indeed to hear that such prominent military leaders and so many Fortune 500 companies would be lobbying for race-based affirmative action.

While this military and corporate support on instrumental grounds is a surprise to those who view the controversy as centered on rights-based affirmative action, for scholars of organizational behavior it is a predictable feature of a transformation that has been long in the making. ${ }^{73}$ Most importantly, neither the military brief nor the corporate brief defended the University of Michigan admissions policies on civil rights grounds. Instead, the Fortune 500 companies defended race-conscious admissions by arguing that this policy is essential for the functioning of the companies themselves.

The corporate world has largely jumped on the racial diversity bandwagon as diversity professionals have persuaded corporate executives that a racially diverse workforce is important for several reasons. First, businesses' success in the global marketplace depends on employing workers who understand diverse marketplaces and who resemble the variety of racial makeup of the racially diverse customer bases. Second, corporations see a racially diverse workforce as an important recruiting tool—talented, young professionals increasingly view a racially diverse workforce as a valuable feature of their workplace. Third, the Fortune 500 companies' brief argued that, without raceconscious admissions, "the University's graduates will therefore be less likely to possess the skills, experience, and wisdom necessary to work with and serve the diverse populations of the United States and the global community." ${ }^{74}$ Finally, institutionalizing diversity policies and diversity rhetoric strengthens corporations' defenses against lawsuits alleging racial or gender discrimination. ${ }^{75}$

The retired military leaders expressed their own distinct rationales for supporting race-based admissions in higher education. The argument is based on the need for cohesiveness and harmony in a hierarchical institution in which African Americans and Hispanics are overrepresented at the lower enlisted levels and underrepresented at the higher officer positions. The recruits in the lower, enlisted positions tend to come from the lowsocioeconomic rungs of society, for the responsibility, security, and heroism of the military are especially appealing to citizens who are willing to accept the dangers and sacrifices because they see few preferable occupational opportunities. ${ }^{76}$ As a result, it should be no surprise that African Americans and Hispanics-who are overrepresented nationally in the lower socioeconomic levelswould be overrepresented at the lower, enlisted positions of the military. According to the brief, "today, almost $40 \%$ of servicemen and women are minorities; $61.7 \%$ are white, and the remaining almost $40 \%$ are minorities, including 21.7\% African-American, 9.6\% Hispanic, 4\% Asian-American and 1.2\% Native American."77
The military brief is remarkable in its tone, as the authors argue that the continuation of race-conscious admissions in the Reserve Officers' Training Corps (ROTC) and the military academies is essential for the military, which in the 1970s was on the verge of self-destruction because of racial tensions. According to the brief, the stakes are incredibly high: "A substantial difference between the percentage of African-American enlisted personnel (21.7\%) and African-American officers (8.8\%) remains. The officer corps must continue to be diverse or the cohesiveness essential to the military mission will be critically undermined." The brief raises concerns that many enlisted personnel of color are troubled by how their largely white superiors treat them. The retired military leaders argued that affirmative action is necessary to increase the pool of officers of color: "At present, the military cannot achieve an officer corps that is both highly qualified and racially diverse unless the service academies and the ROTC use limited race-conscious recruiting and admissions policies."

The corporate and military support poses a major obstacle to the conservative colorblind cause. Major corporations were successfully rallied by the Republican Mayor of Houston to oppose Measure A, a ballot measure to ban race-based affirmative action in the public sector. ${ }^{78}$ While conservative millionaires, including Steve Forbes and Rupert Murdoch, and wealthy conservative foundations provide extensive funding to the colorblind ballot initiatives (the 1996 Proposition 209 in California, the 1998 Initiative 200 in Washington state, and the 2006 Proposal 2 in Michigan), ${ }^{79}$ the major corporations in each state funded the pro-affirmative action causes in all three states. ${ }^{80}$ In the case of Proposal 2, dozens of Michigan business leaders were among the co-chairs for One United Michigan, the coalition in Michigan defending affirmative action against Proposal $2 .{ }^{81}$ This included leaders of AT\&T Michigan, Blue Cross-Blue Shield of Michigan, Henry Ford Health System, General Motors Corporation, Ford Motor Company, and DaimlerChrysler Corporation. ${ }^{82}$

While corporate leaders may be becoming more vocal about their support for race-conscious diversity policies in the past decade, this business case for race-conscious diversity policies is by no means new. Many scholars have documented the emergence of a significant business case for affirmative action during the 1980s. ${ }^{83}$ As the next section explains, support for affirmative action among the Republican leadership has similarly become more vocal in the past decade even though it can be traced back even a generation earlier.

\section{Where Are the Republican Leaders against Affirmative Action?}

According to the conventional civil rights framework, liberals and Democrats generally support race-based affirmative action while conservatives and Republicans largely 
identify with the colorblind agenda. Numerous contemporary scholars of affirmative action continue to view affirmative action through this civil rights framework. ${ }^{84}$ While I do not deny that much of the vocal and active contemporary opposition to affirmative action originates from conservative Republicans, I emphasize in this section how little support the colorblind cause finds among Republican leaders.

Republican strategists have wisely counseled Republican lawmakers to tread carefully before following in the footsteps of former California Governor Pete Wilson, who sought to gain politically from an anti-affirmative action agenda. In his memoir, Ward Connerly is highly critical of numerous Republicans_-including Colin Powell and J.C. Watts-for supporting race-based affirmative action and of many more-including Bob Dole, Elizabeth Dole, George H. W. Bush, George W. Bush, Jeb Bush, and Jack Kemp-for waffling or distancing themselves from the "colorblind" cause. ${ }^{85}$ Former Michigan Republican Party Chairwoman Betsy DeVos and 2006 Republican gubernatorial candidate Dick DeVos both publicly voiced their support for race-based affirmative action and explicitly opposed the 2006 Proposal 2. In addition, many Republican incumbents for state legislative races and both leading Republican challengers unsuccessfully seeking to unseat U.S. Democratic Senator Debbie Stabenow voiced their support for race-based affirmative action and opposition to Proposal 2. ${ }^{86}$ Meanwhile, the Michigan Civil Rights Institute (the in-state organization established by Ward Connerly to mobilize support for Proposal 2) did not identify any major Michigan businesses, organizations, or prominent political leaders who publicly lined up in favor of Proposal 2. ${ }^{87}$ The strategy of One United Michigan was to paint the supporters of Proposal 2 as a small faction of out-of-state extremists-led by a millionaire California businessman (namely, Ward Connerly) — who were out of touch with Michigan. While Proposal 2 won in a landslide by winning 58 percent of the votes, its organizers did so without a visible coalition.

The One United Michigan leaders believed that they could win on Election Day by framing the vote on Proposal 2 in terms of women's issues rather than racial issues. The specific strategy was to expose numerous programs for women and girls that could be ended if Proposal 2 passed. Television advertisements and leaflets raised alarms that programs to recruit elementary and middle school girls to pursue science would be banned along with breast cancer screening programs. The polling firm that contracted with One United Michigan persuaded the coalition that women were the key demographic to target, and that the way to target women would be to focus on their self-interest in preserving vulnerable women's programs.

The coalition determined that it could not avoid addressing racial issues, and this anti-Proposal 2 coalition followed the racial diversity playbook in its mobilization strategy. University presidents across the state spoke out about the importance of preserving racial diversity on their campuses. One United Michigan relied heavily on its support from major corporations located in Michigan, including the "Big Three" automobile companies. Meanwhile, One United Michigan distanced itself from the more confrontational messages from the By Any Means Necessary (BAMN) civil rights group. In addition, the coalition made sure to highlight that the conservative Republican millionaire gubernatorial candidate Dick DeVos and other top Republican leaders in the state supported affirmative action and opposed Proposal 2. By framing the antiaffirmative action side as a group of outside agitators led by a rich California businessman, One United Michigan sought to capture the populist fervor and regionalism of ordinary Michigan voters.

However, the focus on government, corporate, and higher education elites went counter to the populist angle by placing elites rather than ordinary Michigan people in the limelight. By portraying affirmative action as a diversity issue that had gained the passionate support of Michigan's leading businesses and universities, the affirmative action coalition sought to ride the new wave of diversity rather than employing the older, divisive civil rights framework. But by raising the alarm on women's issues and downplaying racial issues, the coalition may have erred by ceding rights-talk on racial issues to the colorblind cause.

What about the Republican stance in the university affirmative action cases? How, when, or whether the Bush administration would come out on the Gratz and Grutter cases wasn't clear. On the one hand, opposing the University of Michigan affirmative action policies would appease the Republican Party's conservative base. On the other hand, the Bush campaign and Republican Party in general has carefully focused on winning over increasing proportions of the rapidly expanding Hispanic population, only one third of which voted for Republican candidate George W. Bush in the 2000 election. ${ }^{88}$

Bush ultimately chose to take a public stand against race-based affirmative action and directed then-Solicitor General Theodore Olson-the former Washington chapter president of the conservative Federalist Society, ${ }^{89}$ who had a clear track-record of opposing race-based affirmative action - to file briefs opposing the University of Michigan Law School and undergraduate policies. ${ }^{90}$ Indeed, Olson had successfully represented plaintiff Cheryl Hopwood in her "reverse discrimination" case against the raceconscious admissions policy at the University of Texas Law School in Hopwood v. Texas. ${ }^{91}$ Olson explicitly argued in Hopwood that diversity is not a compelling state interest, and in its decision the Fifth Circuit Court of Appeals agreed.

However, the Bush administration's stance was instead a remarkably weak legal argument against affirmative 
action, and indeed was so weak that it barely deserves to be labeled an anti-affirmative action brief. Instead of calling for the Court to rule that diversity is not a compelling governmental interest, the Solicitor General's brief punted on this pivotal issue. Indeed, the brief went so far as to praise racial diversity as "an important and entirely legitimate government objective," 92 essentially conceding that the Bush administration was not challenging the diversity rationale. This could not have been an oversight. Instead, the brief remained within the perceived "safe zone" of politics, choosing to stay within the "boundaries of legitimacy" 93 by accepting — rather than challenging-racial diversity policymaking.

Instead of calling for the Court to overturn Bakke, the landmark 1978 case upholding the constitutionality of racial preferences in university admissions as a tool to produce a racial diverse student body, the Bush administration brief explicitly conceded that, "in the end, this case requires this Court to break no new ground to conclude that respondents' race-based admissions policy is unconstitutional." Contrast this with the plaintiffs brief, filed by the Center for Individual Rights, which explicitly argued that ". . . the diversity interest relied upon by the Law School is inherently unsuited to be a compelling interest." 94 Instead of claiming that diversity is not a compelling government interest, the Bush administration brief challenged the University of Michigan Law School policy by arguing that it was in effect a quota and hence not narrowly tailored as required by the Court's equal protection jurisprudence. That is, the Bush administration's strategy was to reaffirm Bakke and instead challenge the means as not being narrowly tailored rather than challenging the ends as not being compelling.

Ward Connerly, Carl Cohen, and numerous other colorblind leaders and scholars have expressed their dismay at the administration's legal brief for its failure to centrally challenge the University of Michigan's core claim that diversity is a compelling state interest justifying its raceconscious admissions policy. ${ }^{95}$ To this day, Ward Connerly remains furious with President Bush for taking what he calls a "Clinton-esque," waffling, spineless stance on Gratz and Grutter. 96 The core constitutional issue at stake was whether the Court would find diversity to be a compelling state interest. The majority's holding in Grutter that diversity is a compelling state interest was a major blow. The Bush administration's failure to object to the diversity rationale was yet one more sign of the Republican Party leadership's concerted move to distance itself from the colorblind cause.

It is understandable from an electoral-incentive perspective that the Bush campaign would want to avoid news headlines that might insinuate that Bush in some way opposed or rejected racial diversity. To argue that diversity is not a compelling state interest is to risk alienating large segments of the voting public that revere racial diversity. Campaign consultants_-particularly Karl Rovehave advised Bush and other Republican leaders that the future of the Republican Party depends on increasing the Party's share of the Hispanic vote. Bush and other top Republican Party leaders have shifted away from explicit race-baiting and toward a "compassionate conservative" agenda ${ }^{97}$ that is based on a discourse of racial inclusion. It appears that the administration sought to stake out a moderate position in order to have it both ways. Regardless of the outcome of the two court cases, Bush would show his symbolic support for the anti-affirmative action views that his Republican base holds without taking the risky move of challenging the value of racial diversity.

The Supreme Court's 2007 decision in Parents Involved in Community Schools v. Seattle School District No. 1 striking down the Seattle and Louisville school districts' integration plans actually further rooted the Grutter defense of affirmative action in equal protection jurisprudence. Whereas many experts had predicted that this case would serve as the occasion for the newly-configured Roberts Court to chip away at-or explicitly ban-affirmative action by ruling that race-conscious diversity policies are never narrowly tailored or that diversity is never a compelling interest to justify such racial preferences, the conservative Court left its own 2003 Grutter ruling solidly intact. So long as the measures are narrowly tailored to achieve the compelling state interest in diversity, the Court has indicated that it plans to uphold race-based diversity measures in K-12 and higher education.

The Court objected to both of the challenged voluntary, school-assignment plans in part because the districts classified students only as white or "nonwhite" in the case of Seattle and black or "other" in the case of Jefferson County. Whereas the Court in Grutter held that race may be one of many factors taken into account in raceconscious diversity policies, in this school integration decision the Court found that race had been the sole factor that districts had considered in assigning students to their schools and explicitly relied on Gratz and Grutter to criticize the school districts for their failure to conduct an individualized review. ${ }^{98}$ The majority opinion also objected to both districts' policies for "working backward to achieve a particular type of racial balance, rather than working forward from some demonstration of the level of diversity," calling this "a fatal flaw under our existing precedent" in Grutter and elsewhere. ${ }^{99}$ While the majority opinion by Chief Justice Roberts struck down both the Seattle and Louisville school integration plans, the decision did so narrowly by applying, rather than chipping away or overturning, Grutter.

The Court was very divided in this decision, as the dissenting justices accused the Court of chipping away at Brown v. Board of Education and accelerating the resegregation of public school districts. But the civil rights activists had in another sense dodged a bullet. The newly 
configured conservative majority on the Court could have used this decision as a launching pad to gut the Court's affirmative action rulings. Instead, the Court further reinforced Grutter, securing the constitutional foundations for race-conscious diversity policies provided that institutions adhere to the Court's directives to rely on individualized review and to avoid relying on the diversity rationale largely as a cover for "racial balancing." Of course, only time will tell how the Court will apply its own jurisprudence in the inevitable litigation to come.

The strategic decision by supporters - in both the University of Michigan litigation and the 2006 Proposal 2 in Michigan - to eschew civil rights arguments in favor of diversity arguments has created a vacuum in "equality talk," ${ }^{100}$ providing colorblind entrepreneurs with the opportunity to pursue a legal strategy based on rightsbased conservatism. ${ }^{101}$ Whereas the proponents have emphasized utilitarian arguments by corporations and the military, the conservative colorblind leaders have laid claim to the civil rights legacy of Martin Luther King, Jr., and the broader civil rights movement of the 1960s. The irony is that both the pro-affirmative action civil rights activists and the colorblind civil rights activists feel marginalized from the decisionmaking on a policy that continues to be seen-by journalists, the media, and legal/ political experts—as a core civil rights policy.

\section{Conclusion}

The often-predicted demise of race-based inclusion policies by the increasingly conservative federal judiciary has not yet occurred. While recent scholars commonly predict that affirmative action and other related racial inclusion policies are on the verge of extinction because of a conservative colorblind "assault on diversity," 102 this article instead argues that such race-based affirmative action policies have rather deepened their roots in the United States as a result of the rise of racial diversity policies.

Admittedly, colorblind political entrepreneurs have succeeded in banning race-based and gender-based affirmative action via gubernatorial action in Florida ${ }^{103}$ and via ballot measures in California, ${ }^{104}$ Washington State, ${ }^{105}$ and Michigan ${ }^{106}$ - and they are planning to extend the bans to numerous additional states in the 2008 elections. Not surprisingly, the landslide colorblind victory in Michigan in 2006 has restored the momentum for organizing further ballot measures. Ward Connerly has already set the wheels in motion for anti-affirmative action ballot initiatives in 2008 in numerous states, including Colorado and Nebraska. ${ }^{107}$ This threat is real-the ballot measure approach has been a very successful political mobilization strategy for the colorblind cause.

That said, race-conscious diversity policies are still alive and well in the vast majority of states and at the national level. Now that the U.S. Supreme Court has rejected the colorblind argument in Grutter, the critics of affirmative action have few choices besides pushing ballot measures and hoping that recent or future turnover on the Supreme Court will result in colorblind judicial victories. However, I do not mean to suggest that the judicial—or direct democracy-battle over affirmative action has ended. Given the razor-thin margin of the Grutter vote, it is conceivable that the appointments of Justice Alito and Chief Justice Roberts could yet lead to an anti-affirmative action majority on the Court. Nonetheless, I argue in this article that affirmative action has become increasingly entrenched in American policy and politics at a time when many experts had good reason to predict its extinction. And while affirmative action endures in all but a few states, the particularly version of affirmative action that is becoming entrenched bears limited resemblance to affirmative action as understood via the civil rights framework. Whereas affirmative action as properly conceived-in the form of race-based civil rights measures that are rooted in corrective justice rationalesmay be in decline, it still endures. And affirmative action in its modern reincarnation, that is, in the form of a utilitarian, race-based inclusion policy that is rooted in organizations' goals of achieving diversity for their own instrumental reasons, is thus far relatively entrenched.

Not only have the justifications for affirmative action shifted from corrective justice to utilitarian diversity, but so too have the distributive outcomes of who become the recipients of affirmative action. When diversity practices are detached from policies rooted in backward-looking corrective justice rationales, organizations instead achieve the diversity they seek instrumentally in such ways that eschew civil rights foundations and instead are grounded in present- and forward-looking organizational utility.

I conclude by highlighting the numerous calls by affirmative action scholars for a renewed commitment to rightsbased affirmative action. Numerous affirmative action scholars and activists have raised concerns about the detachment of civil rights roots from affirmative action, calling attention to the dangers of this transformation and propose specific reforms to reattach affirmative action to its civil rights roots. According to this approach, affirmative action must be primarily directed toward corrective justice measures to promote equality and opportunity for members of marginalized racial minorities. Many scholars who embrace this approach argue that expanding social welfare programs along the lines of the Great Society programs will be necessary in order to truly address the structural problems facing low socio-economic status African Americans, American Indians, and Hispanics (as well as low SES whites). ${ }^{108}$ Some view affirmative action as a core policy needing to exist alongside this expansive social welfare agenda. Others view affirmative action as an important, but nonetheless peripheral, policy. ${ }^{109}$ Regardless of its central versus peripheral nature, these scholars have 
developed specific, creative proposals for how to restore affirmative action's civil rights origins.

Such proponents of restoring affirmative action to a corrective justice policy have emphasized the need to limit the beneficiaries to historically marginalized groups that endured institutional or societal discrimination. Toward this end, Patterson calls for limiting affirmative action to lower- and working-class recipients from the following racial/ethnic identities: Afro Americans, Puerto Ricans, second and third generation Mexican Americans, and Chinese-Americans descended from pre-1923 immigrants. ${ }^{10}$

Glazer, who shifted from being a leading critic to being a vocal supporter of affirmative action, ${ }^{111}$ would limit affirmative action to African Americans. And Katznelson proposes "that affirmative action focus on antidotes to specific harms that date back to national policies in the 1930s and 1940 s as remedies for the deep, even chronic dispossession that continues to afflict a large percentage of black America." 112 In contrast to Clinton's call to "mend, not end, it," Katznelson proposes to "extend affirmative action in order to end it within one generation." 113 Welch and Gruhl also agree that "one possibility is to narrow the scope of federal affirmative action coverage to those groups that historically suffered substantial discrimination and continue to do so. There may already be a consensus that immigrants should not be covered by affirmative action." 114

Katznelson calls for affirmative action to be restored to the vision articulated by Justice Powell in Bakke and President Johnson in his Howard University address. According to this logic, "affirmative action is constitutional... when the discrimination being remedied is specific, identifiable, and broadly institutional." 115 For example, he proposes that the U.S. government identify which African Americans were excluded by design from Social Security benefits from its inception during the New Deal; then, the government could offer "one-time grants that would have to be paid into designated retirement funds" to them or their heirs. Tax credits could be extended to remedy the "absence of access to the minimum wage." And "programs of subsidized mortgages, small business loans, and educational grants" could be developed to make up for blacks' exclusion. ${ }^{116}$ Alternatively, Katznelson offers an administratively less burdensome proposal to extend basic health insurance, an expanded Earned Income Tax Credit, subsidized mortgages, education and training grants, small business loans, job searching and placement, and generous child care to "poor Americans who face conditions produced by the constellation of patterns of eligibility and administration the South placed inside the most important New Deal and Fair Deal programs." 117

Renewing affirmative action in its original civil rights design has the potential to bridge some of the divide between the affirmative action and colorblind sides. The colorblind leaders converge with Katznelson's and Patterson's calls for race-based affirmative action to be tied to concrete acts of discrimination and to end within one generation. ${ }^{118}$ In addition, it satisfies the concerns of so many citizens and leaders who are ambivalent about affirmative action because of their perception that it has become a policy of "racial balancing" that benefits privileged blacks and Hispanics who haven't suffered pervasive disadvantages or subordination at the expense of disadvantaged whites and Asians. Whether lawmakers embrace this re-visioning of affirmative action as civil rights policy remains to be seen. Regardless, commitments to racial inclusion policies remain firm for now at least, albeit for utilitarian more than egalitarian reasons.

\section{Notes}

1539 U.S. 306 (2003); Michigan Compiled Law Service (MCLS) Const. Art. I, $\$ 26$ (2007) (Chapter 1: Constitution of the State of Michigan, Article I, Declaration of Rights, $\$ 26$. Affirmative action programs.)

2 Fiss 1976, Siegel 2004.

3 Balkin and Siegel 2003; Siegel 2004, 1472-73.

4 Balkin and Siegel 2003; Siegel 2004, 1470.

5 Glazer 1987.

6 Bobo 1998; Anderson 2004; Klinkner and Smith 1999; Bobo, Kluegel, and Smith 1997; Dudas 2005; Goldberg-Hiller and Milner 2003, Kinder and Sanders 1996; Klinkner and Smith 1999; Sears, Van Laar, and Carrillo 1997; Sears, Sidanius, and Bobo 2000.

7 Connerly 2000, 23.

8 Ibid., 22.

9 Anderson 2004, 277; Frymer and Skrentny 2004; Glazer 1988, Hochschild 1998; Lynch 1997, Stohr 2004.

10 Frymer and Skrentny 2004, 681.

11 Kellough 2006, 68.

12127 S. Ct. 2738 (2007).

13 Anderson 2004; Edelman et al. 2001; Kelly and Dobbin 1998.

14 Kellough and Naff 2004; Kelly and Dobbin 1998.

15 Anderson 2004, 158; Bacchi 1996; Cohen and Sterba 2003; Glazer 1987, x-xi and 2005 Kellough 2006, 31; Smelser, Wilson, and Mitchell 2001.

16 Anderson 2004, 273.

17 Kelly and Dobbin 2001, 113.

18 Massey and Mooney 2007, 99.

19 Katznelson 2005.

20 Kinsley 2003.

21 Katznelson 2005, 168.

22 Ibid., 116, 273, Graham 1992, Kellough 2006, 31, Skrentny 1996, 2002b.

23 Guinier and Sturm 2001.

24 Johnson 1966. 
25438 U.S. 265 (1978) Blackmun, J. dissenting

26 Cohen and Sterba 2003, Kellough 2006, 83-92.

27 Plessy v. Ferguson 163 U.S. 537 (1896) Harlan, J. dissenting.

28 Cohen 1995, Eastland 1996, Glazer 1987, Kull 1992.

29 Kennedy 1963.

30 Skrentny 1996, 2002b.

31 Glazer 1999, Patterson 1998, Skrentny 2002a.

32 Skrentny 1996, 2002 b.

33 Anderson 2004, 236-40.

34 Lipson 2007.

35 Skrentny 2002b.

36 Connerly 2000, 22.

37 Ibid.

38 Karabel 2005, 408.

39 Graham 1989, 1992, Skrentny 1996, 2002 b.

40 Anderson 2004, 236-40.

41 Frymer and Skrentny 2004, 721.

42 Ibid, Karabel 2005, Skrentny 1996, 2002b; Downs 1999, Karabel 2005.

43 Edelman et al. 2001, Frymer and Skrentny 2004, Kelly and Dobbin 1998; Edelman 1990, Edelman et al. 1991, Edelman and Suchman 1997, Kellough 2006, Thomas 1990, 1991, 1993, 1996.

44 Frymer and Skrentny 2004, 706; Johnston, Packer, and United States Department of Labor 1987; Kelly and Dobbin 2001, 103-104.

45 Thomas 1990.

46 Kelly and Dobbin 2001, 109.

47 Kellough 2006, 69.

48 Thomas 1990, 107.

49 Kellough 2006, 69.

50 Ibid., 68.

51 Barnes and Burke 2006; Edelman 1990, 1992; Edelman, Fuller and Mara-Drita 2001; Edelman et al. 1991; Edelman and Suchman 1997, Kellough 2006; Kelly and Dobbin 1998; Pedriana and Abraham 2006.

52 Kelly and Dobbin 2001, 111.

53 Ibid.

54 Ibid., 109.

55 Ibid., 111.

56 Anderson 2004, 236.

57 Skrentny 2002b.

58 Anderson 2004, 237.

59 Massey et al. 2007.

60 Anderson 2004, 237.

61 Douglass 2007, Karabel 2005.

62 Kahlenberg 1996, Welch and Gruhl 1998.

63 Karabel 2005, Lipson 2007; Welch and Gruhl 1998, 136.

64 Lipson 2001, 2007.

65 Lipson 2001.
66 Chavez 1998, Cokorinos 2003, Dudas 2005, Goldberg-Hiller and Milner 2003, Keck 2006, Klinkner and Smith 1999, Walton and Smith 2003.

67539 U.S. 244 (2003)

68 Karabel 2005, 498.

69 Kellough 2006.

70539 U.S. 330-331 (2003)

71 For example, see Epstein and Walker 2003, 768.

72 Carmines and Stimson 1989, Klinkner and Smith 1999, Mendelberg 2001, Skrentny 1996.

73 Edelman, Fuller, and Mara-Drita 2001; Frymer and Skrentny 2004; Glazer 1988; Kelly and Dobbin 1998, Lynch 1997, Schuck 2003.

$743 \mathrm{M}$ et al. Grutter v. Bollinger and Gratz v. Bollinger: Brief for Amici Curiae: 65 Leading American Businesses in Support of Respondents.

75 Katznelson 2005, 158.

76 Klinkner and Smith 1999.

77 Department of Defense (“DoD”), Statistical Series Pamphlet No. 02-5, Semiannual Race/Ethnicl GenderProfile By Service/Rank of the Department of Defense \& Coast Guard 4 (Mar. 2002) ("DoD Report")

78 Connerly 2000, Kellough 2006.

79 Cokorinos 2003.

80 Connerly 2000.

81 Ankeny 2006.

82 See the following list for names and titles of these leaders: AT\&T Michigan President Gail Torreano; International Brotherhood of Teamsters General President James P. Hoffa; Walbridge Aldinger Co. Chairman and CEO John Rakolta Jr.; and DTE Energy Corp. CEO and Chairman Tony Earley, Blue Cross-Blue Shield of Michigan CEO designate Daniel Loepp; United Auto Workers President Ron Gettelfinger; Bing Steel Chairman and CEO Dave Bing; New Detroit Inc. President and CEO Shirley Stancato; Detroit Renaissance Inc. President and CEO Doug Rothwell; Henry Ford Health System President and CEO Nancy Schlichting; Strategic Staffing Solutions President and CEO Cynthia Pasky; Tom Gottschalk, General Counsel and Executive Vice President for Public Policy, General Motors Corp.; Tim O'Brien, Deputy Chief of Staff, Ford Motor Co.; Frank Fountain, Senior Vice President for External Affairs and Public Policy, DaimlerChrysler Corp.; Archbishop of Detroit and Chairman of the Michigan Catholic Conference Cardinal Adam Maida; and Dennis Archer, Board Chairman of Dickinson Wright P.L.L.C.

83 Anderson 2004, Glazer 1988, Kelly and Dobbin 1998.

84 For two examples, see Kellough 2006, 52, Welch and Gruhl 1998, 151.

85 Connerly 2000. 
86 Butler 2005.

87 That is, except for Michigan Civil Rights Institute State Chairman Leon Drolet, who served in the Michigan House of Representatives from 2000 to 2006.

88 Hulse 2003.

89 Cokorinos 2003.

90 Stohr 2004.

9178 F.3d 932 (1996)

92 Brief for the United States as Amicus Curiae Supporting Petitioner

93 Skrentny 1996.

94 Brief for the Petitioner, Grutter v. Bollinger, No. 02-241.

95 Connerly 2004a.

96 Connerly 2004b.

97 Hutchings et al. 2004; Kuypers et al. 2003.

98127 S. Ct. 2738 (2007)

99127 S. Ct. 2738 (2007)

100 Siegel 2004

101 Keck 2006.

102 Anderson 2004, Chavez 1998, Cokorinos 2003, Guerrero 2002, Hochschild 1998, Klinkner and Smith 1999, Lipsitz 2006, Orfield and Miller 1998, Welch and Gruhl 1998.

103 Bush 2000.

104 Alvarez and Bedolla 2004, Chavez 1998, Conrad and Sharpe 1996, Douglass 1999, 1998, Gibbs and Bankhead 2001, Guerrero 2002, Karabel 1998, 1999, Ong 1999, Schrag 1998, Taylor 1999.

105 Journal of Blacks in Higher Education 2002, Brown and Hirschman 2006.

106 Michigan Civil Rights Commission 2007.

107 Schmidt 2007. Connerly will likely try again to get his initiatives on the ballot in Arizona, Missouri, and Oklahoma.

108 Klinkner and Smith 1999, Lipsitz 2006, Welch and Gruhl 1998, 174, Wilson 1990, 2001.

109 Welch and Gruhl 1998, 169.

110 Patterson 1998, 193.

111 Glazer 1975; 1999, 2005.

112 Katznelson 2005, xi.

113 Ibid.

114 Welch and Gruhl 1998, 171.

115 Katznelson 2005, 160.

116 Ibid., 171.

117 Ibid., 171-72.

118 Ibid., 172, Patterson 1998, 193.

\section{References}

Alvarez, R Michael, and Lisa Garcia Bedolla. 2004. The revolution against affirmative action in California: Racism, economics, and Proposition 209. State Politics \& Policy Quarterly 4 (1): 1-17.
Anderson, Terry H. 2004. The Pursuit of Fairness: A History of Affirmative Action. New York: Oxford University Press.

Ankeny, Robert. 2006. "Business Leaders Join Coalition to Fight Effort to Ban Affirmative Action." Crain's Detroit Business, April 6.

Bacchi, Carol Lee. 1996. The Politics of Affirmative Action: "Women", Equality and Category Politics. London: Sage Publications.

Balkin, Jack M., and Reva B. Siegel. 2003. The American civil rights tradition: Anticlassification or Antisubordination (response to article by Owen Fiss, Philosophy and Public Affairs, Vol. 5, P. 107, 1976). Issues in Legal Scholarship 5.

Barnes, Jeb, and Thomas F. Burke. 2006. The diffusion of rights: From law on the books to organizational rights practices. Law \& Society Review 40 (3): 493-523.

Bobo, Lawrence. 1998. Race, interests, and beliefs about affirmative action. American Behavioral Scientist 41 (7): 985-1003.

Bobo, Lawrence, James R. Kluegel, and Ryan A. Smith. 1997. Laissez-faire racism: The crystallization of a kinder, gentler, antiblack ideology. In Racial Attitudes in the 1990s: Continuity and Change, ed. Steven A. Tuch and Jack K. Martin. Westport, Conn.: Praeger.

Brown, Susan K, and Charles Hirschman. 2006. The end of affirmative action in Washington state and its impact on the transition from high school to college. Sociology of Education 79 (2): 106-30.

Bush, Jeb. 2000. "Better Than Affirmative." New York Times, September 15, 35.

Butler, Keith. 2005. Keith Butler statement regarding Ward Connerly ballot initiative. http://www. oneunitedmichigan.org/pdf/Butler-statement2.pdf

Carmines, Edward G., and James A. Stimson. 1989. Issue Evolution: Race and the Transformation of American Politics. Princeton, NJ: Princeton University Press.

Chavez, Lydia. 1998. The Color Bind: California's Battle to End Affirmative Action. Berkeley: University of California Press.

Cohen, Carl. 1995. Naked Racial Preference. Lanham, MD: Madison Books.

Cohen, Carl, and James P. Sterba. 2003. Affirmative Action and Racial Preference: A Debate. New York: Oxford University Press.

Cokorinos, Lee. 2003. The Assault on Diversity: An Organized Challenge to Racial and Gender Justice. Lanham, MD: Rowman \& Littlefield.

Connerly, Ward. 2000. Creating Equal: My Fight against Race Preferences. San Francisco: Encounter Books.

- 2004a. Interview on May 6.

- 2004b. Lecture at Kalamazoo College. Kalamazoo, MI.

Conrad, Cecilia A, and Rhonda V Sharpe. 1996. The impact of the California Civil Rights Initiative (CCRI) 
on university and professional school admissions and the implications for the California economy. The Review of Black Political Economy 25: 13-59.

Douglass, John Aubrey. 1998. Anatomy of conflict: The making and unmaking of affirmative action at the University of California. The American Behavioral Scientist 41 (7): 938-959.

- 1999. The evolution of a social contract: The University of California before and in the aftermath of affirmative action. European Journal of Education 34 (4): 393-412.

- 2007. The Conditions for Admission: Access, Equity, and the Social Contract of Public Universities. Stanford, Calif:: Stanford University Press.

Downs, Donald Alexander. 1999. Cornell '69: Liberalism and the Crisis of the American University. Ithaca, NY: Cornell University Press.

Dudas, Jeffrey R. 2005. In the name of equal rights: "Special" rights and the politics of resentment in post-civil rights America. Law \& Society Review 39 (4): 723-57.

Eastland, Terry. 1996. Ending Affirmative Action: The Case for Colorblind Justice. New York: Basic Books.

Edelman, Lauren B. 1990. Legal environments and organizational governance: The expansion of due process in the American workplace. The American Journal of Sociology 95 (6): 1401-40.

- 1992. Legal ambiguity and symbolic structures: Organizational mediation of civil rights law. The American Journal of Sociology 97 (6): 1531-76.

Edelman, Lauren B., Sally Riggs Fuller, and Iona MaraDrita. 2001. Diversity rhetoric and the managerialization of law. The American Journal of Sociology 106 (6): 1589-641.

Edelman, Lauren B., Stephen Petterson, Elizabeth Chambliss, and Howard S. Erlanger. 1991. Legal ambiguity and the politics of compliance: Affirmative action officers' dilemma. Law \& Policy 13: 73-97.

Edelman, Lauren B., and Mark C. Suchman. 1997. The legal environments of organizations. Annual Review of Sociology 23: 479-515.

Epstein, Lee, and Thomas G. Walker. 2003. Constitutional Law for a Changing America: Rights, Liberties, and Justice. Washington, DC: CQ Press.

Fiss, Owen M. 1976. Groups and the equal protection clause. Philosophy \& Public Affairs 5: 107.

Frymer, Paul, and John D. Skrentny. 2004. Symposium: The rise of instrumental affirmative action: Law and the new significance of race in America. Connecticut Law Review 36: 677-723.

Gibbs, Jewelle Taylor, and Teiahsha Bankhead. 2001. Preserving Privilege: California Politics, Propositions, and People of Color. Westport, CT: Praeger.

Glazer, Nathan. 1975. Affirmative Discrimination: Ethnic Inequality and Public Policy. New York: Basic Books.
1987. Affirmative Discrimination: Ethnic Inequality and Public Policy. Cambridge, MA: Harvard University Press.

- 1988. The affirmative action stalemate. The Public Interest 90: 99.

- 1999. The case for racial preferences. The Public Interest 135: 45-63.

. 2005. Thirty years with affirmative action. $D u$

Bois Review: Social Science Research on Race 2 (1): 5-15.

Goldberg-Hiller, Jonathan, and Neal Milner. 2003. Rights as excess: Understanding the politics of special rights. Law \& Social Inquiry 28 (4): 1075-118.

Graham, Hugh Davis. 1989. The Civil Rights Era: Origins and Development of National Policy, 1960-1972. New York: Oxford University Press.

1992. The origins of affirmative action: Civil rights and the regulatory state. The Annals of the American Academy of Political and Social Science 523: 50-62.

Guerrero, Andrea. 2002. Silence at Boalt Hall: The Dismantling of Affirmative Action. Berkeley: University of California Press.

Guinier, Lani, and Susan Sturm. 2001. Who's Qualified? Boston: Beacon Press.

Hochschild, Jennifer L. 1998. The future of affirmative action: The strange career of affirmative action. Ohio State Law Journal 59: 997-1037.

Hulse, Carl. 2003. Democrats design agenda in bid to hold Hispanic support. New York Times, July 10.

Hutchings, Vincent L., Nicholas A. Valentino, Tasha S. Philpot, and Ismail K. White. 2004. The compassion strategy: Race and the gender gap in campaign 2000. Public Opinion Quarterly 68 (4): 512.

Johnson, Lyndon B. 1966. To fulfill these rights: Commencement address at Howard University. In Public Papers of the Presidents of the United States: 635-640. Washington, DC: Government Printing Office.

Johnston, William B., Arnold E. Packer, and United States Dept. of Labor. 1987. Workforce 2000: Work and Workers for the Twenty-First Century. Indianapolis, IN: Hudson Institute; U.S. Dept. of Labor.

Kahlenberg, Richard D. 1996. The Remedy: Class, Race, and Affirmative Action. New York: BasicBooks.

Karabel, Jerome. 1998. No alternative: The effects of color-blind admissions in California. In Chilling Admissions: The Affirmative Action Crisis and the Search for Alternatives, ed. Gary Orfield and Edward Miller: 33-50. Cambridge, MA: Civil Rights Project Harvard University: Harvard Education Pub. Group.

- 1999. The rise and fall of affirmative action at the University of California. Journal of Blacks in Higher Education 25: 109. 
2005. The Chosen: The Hidden History of Admission and Exclusion at Harvard, Yale, and Princeton. Boston: Houghton Mifflin.

Katznelson, Ira. 2005. When Affirmative Action Was White: An Untold History of Racial Inequality in Twentieth-Century America. New York: W.W. Norton.

Keck, Tom. 2006. From Bakke to Grutter: The rise of rights-based conservatism. In The Supreme Court and American Political Development, ed. Ronald Kahn and Ken I. Kersch. Lawrence, KS: University Press of Kansas.

Kellough, J. Edward, and Katherine C. Naff. 2004. Responding to a wake-up call: An examination of federal agency diversity management programs. Administration \& Society 36 (1): 62-90.

Kellough, J. Edward. 2006. Understanding Affirmative Action: Politics, Discrimination, and the Search for Justice. Washington, DC: Georgetown University Press.

Kelly, Erin, and Frank Dobbin. 1998. How affirmative action became diversity management: Employer response to antidiscrimination law, 1961 to 1996. The American Behavioral Scientist 41 (7): 960-84.

- 2001. How affirmative action became diversity management: Employer response to antidiscrimination law, 1961-1996. In Color Lines: Affirmative Action, Immigration, and Civil Rights Options for America, ed. John David Skrentny. Chicago: University of Chicago Press.

Kennedy, John F. 1963. Civil Rights Address June 11, 1963. www.americanrhetoric.com/speeches/ johnfkennedycivilrights.htm.

Kinder, Donald R. and Lynn M. Sanders. 1996. Divided by Color: Racial Politics and Democratic Ideals. Chicago: University of Chicago Press.

Kinsley, Michael. 2003. "How Affirmative Action Helped George W.” Time 161 (4): 70.

Klinkner, Philip A., and Rogers M. Smith. 1999. The Unsteady March: The Rise and Decline of Racial Equality in America. Chicago: University of Chicago Press.

Kull, Andrew. 1992. The Color-Blind Constitution. Cambridge, MA: Harvard University Press.

Kuypers, Jim A., Megan Hitchner, James Irwin, and Alexander Wilson. 2003. Compassionate conservatism: The rhetorical reconstruction of conservative rhetoric. American Communication Journal 6 (4).

Lipsitz, George. 2006. The Possessive Investment in Whiteness: How White People Profit from Identity Politics. Philadelphia: Temple University Press.

Lipson, Daniel N. 2001. Affirmative action as we don't know it: The rise of individual assessment in undergraduate admissions at UC-Berkeley and UT-Austin. In Studies in Law, Politics, and Society, ed. Austin Sarat and Patricia Ewick: 137-84. New York: Elsevier Science Ltd.
2007. Embracing diversity: The institutionalization of affirmative action as diversity management at UC-Berkeley, UT-Austin, and UW-Madison. Law \& Social Inquiry 32 (4).

Look what happens when affirmative action is banned: Black students are pushed down into second-and thirdtier institutions of higher education. 2002. Journal of Blacks in Higher Education 34: 82.

Lynch, Frederick R. 1997. The Diversity Machine: The Drive to Change the 'White Male Workplace'. New York: Free Press.

Massey, Douglas S., and Margarita Mooney. 2007. The effects of America's three affirmative action programs on academic performance. Social Problems 54 (1): 99-117.

Massey, Douglas S., Margarita Mooney, Kimberly C. Torres, and Camille Z. Charles. 2007. Black immigrants and Black natives attending selective colleges and universities in the United States. American Journal of Education 113 (2): 243.

Mendelberg, Tali. 2001. The Race Card: Campaign Strategy, Implicit Messages, and the Norm of Equality. Princeton, NJ: Princeton University Press.

Michigan Civil Rights Commission. 2007. "One Michigan" at the Crossroads: An Assessment of the Impact of Proposal 06-02 by the Michigan Civil Rights Commission. Michigan Department of Civil Rights: 1-66.

Ong, Paul M. 1999. Impacts of Affirmative Action: Policies and Consequences in California. Walnut Creek, CA: AltaMira Press.

Orfield, Gary, and Edward Miller. 1998. Chilling Admissions: The Affirmative Action Crisis and the Search for Alternatives. Cambridge, MA: Civil Rights Project Harvard University: Harvard Education Pub. Group.

Patterson, Orlando. 1998. The Ordeal of Integration: Progress and Resentment in Americas "Racial" Crisis. Washington, DC: Civitas/Counterpoint: Distributed by Publishers Group West.

Pedriana, Nicholas, and Amanda Abraham. 2006. Now you see them, now you don't: The legal field and newspaper desegregation of sex-segregated help wanted ads 1965-75. Law \& Social Inquiry 31 (4): 905-938.

Schmidt, Peter. 2007. "5 States May Curtail Affirmative Action." Chronicle of Higher Education October 19, A1, A19.

Schrag, Peter. 1998. Paradise Lost: California's Experience, America's Future. New York: New Press: Distributed by W.W. Norton.

Schuck, Peter H. 2003. Diversity in America: Keeping Government at a Safe Distance. Cambridge, MA: Harvard University Press.

Sears, David O., Jim Sidanius, and Lawrence Bobo. 2000. Racialized Politics: The Debate About Racism in America. Chicago: University of Chicago Press. 
Sears, David O., Colette Van Laar, and Mary Carrillo. 1997. Is it really racism? The origins of white Americans' opposition to race-targeted policies. Public Opinion Quarterly 61: 16-53.

Siegel, Reva B. 2004. Equality talk: Antisubordination and anticlassification values in constitutional struggles over Brown. Harvard Law Review 117 (5): 1470.

Skrentny, John D. 2002a. Inventing race. The Public Interest 146: 97-113.

Skrentny, John David. 1996. The Ironies of Affirmative Action: Politics, Culture, and Justice in America. Chicago: University of Chicago Press.

- 2002b. The Minority Rights Revolution. Cambridge, MA: Belknap Press of Harvard University Press.

Smelser, Neil J., William J. Wilson, and Faith Mitchell eds. 2001. America Becoming: Racial Trends and Their Consequences. Washington, DC: National Academy Press.

Stohr, Greg. 2004. A Black and White Case: How Affirmative Action Survived Its Greatest Legal Challenge. Princeton: Bloomberg Press.

Taylor, Ula. 1999. Proposition 209 and the affirmative action debate on the University of California campuses. Feminist Studies 25 (1): 95-103.
Thomas, R. Roosevelt. 1990. From affirmative action to affirming diversity. Harvard Business Review 68 (2): 107.

1991. Beyond Race and Gender: Unleashing the Power of Your Total Work Force by Managing Diversity. New York: AMACOM, American Management Association.

1993. From Affirmative Action to Affirming Diversity. West Des Moines, IA: AMI.

. 1996. Redefining Diversity. New York: American Management Association.

Walton, Hanes, and Robert Charles Smith. 2003. American Politics and the African American Quest for Universal Freedom. New York: Longman.

Welch, Susan, and John Gruhl. 1998. Affirmative Action and Minority Enrollments in Medical and Law Schools. Ann Arbor: University of Michigan Press.

Wilson, William J. 1990. The Truly Disadvantaged: The Inner City, the Underclass, and Public Policy. Chicago: University of Chicago Press. . 2001. The Bridge over the Racial Divide: Rising Inequality and Coalition Politics. Berkeley, New York: University of California Press; Russell Sage Foundation. 